\title{
Christine Clark-Evans, The brain and nervous system in two French Renaissance «scientific» poets: Pernette Du Guillet and Guillaume Du Bartas
}

\section{Filippo Fonio}

\section{(2) OpenEdition \\ 1 Journals}

Electronic version

URL: https://journals.openedition.org/studifrancesi/39131

DOI: $10.4000 /$ studifrancesi.39131

ISSN: 2421-5856

Publisher

Rosenberg \& Sellier

\section{Printed version}

Date of publication: 1 December 2004

Number of pages: 350

ISSN: 0039-2944

\section{Electronic reference}

Filippo Fonio, "Christine Clark-Evans, The brain and nervous system in two French Renaissance "Scientific» poets: Pernette Du Guillet and Guillaume Du Bartas", Studi Francesi [Online], 143 (XLVIII | II) | 2004, Online since 30 November 2015, connection on 19 May 2021. URL: http://

journals.openedition.org/studifrancesi/39131; DOI: https://doi.org/10.4000/studifrancesi.39131

This text was automatically generated on 19 May 2021.

\section{cc) (†) $\odot$}

Studi Francesi è distribuita con Licenza Creative Commons Attribuzione - Non commerciale - Non opere derivate 4.0 Internazionale. 


\title{
Christine Clark-Evans, The brain and nervous system in two French Renaissance «scientific» poets: Pernette Du Guillet and Guillaume Du Bartas
}

\author{
Filippo Fonio
}

\section{REFERENCES}

CHRISTINE CLARK-EVANS, The brain and nervous system in two French Renaissance «scientific» poets: Pernette Du Guillet and Guillaume Du Bartas, «Bibliothèque d'Humanisme et Renaissance», LXV, 2, 2003, pp. 189-303.

1 "French Renaissance poets were consumed with their ambitions to know the world and to know human life as the central subject of this world. To this end certain poets educated themselves about theoretical medicine and medical philosophy, particularly Galen, as a part of their curriculum for a proposed new culture", p. 289. La studiosa tenta di delineare i tratti di una fisiologia del cervello e del sistema nervoso secondo la concezione di due poeti del XVI sec., Pernette Du Guillet e Guillaume Du Bartas, prendendo come terminus a quo la pubblicazione del trattato De humani corporis fabrica libri septem di Vesalius (1543), apripista di nuove frontiere dell'anatomia. "These two authors [scil. Pernette Du Guillet e Guillaume Du Bartas] are of particular interest, because they represent both early and late sixteenth-century perspectives, feminine and masculine writing, and contrasts in religious and philosophical outlook [...]", p. 289.

2 Le Rymes di Pernette Du Guillet (1545), poetessa lionese influenzata da Maurice Scève e Louise Labé, partendo dalla concezione platonica dell'amore tracciano una moderna metafisica dei sentimenti. Il nesso fra amore e arte, la corrispondenza di sensi 
amante-amato, i motivi dello sguardo, del desiderio, l'attrazione e il primato dell'anima sul corpo, fanno della concezione erotica della poetessa un platonismo cristiano.

Il sesto giorno de La Sepmaine, ou Création du monde di Guillaume Du Bartas (1578), poema ispirato alla Genesi, è dedicato all'anatomia del primo uomo. L'umanesimo cristiano di Du Bartas è caratterizzato dal frequente ricorso ai classici, in particolare alle teorie mediche di Esculapio, Erofilo e Galeno. Centrali sono il primato accordato alla parola, strumento di comunicazione con Dio, e la conseguente importanza della bocca e della memoria, ma anche una vera e propria disanima del cervello. "In a biblically inspired physiology, speech is established [ ... ] as a faculty that can mysteriously affect and also can be affected by the soul", p. 296.

4 L'interesse di Du Bartas per il cervello e la memoria non è scevro da irriplicazioni etiche ed estetiche: "Fom the aesthetic question of what it means to write poetry on the human body and on the brain, there must arise the ethical question on the universality of the hurman body as source and origin of thinking and mental powers, according to a new metaphysics and according to new concepts of the brain as the organ in control of these physiological processes for all persons", p. 302. 